\title{
Effects of disinfectant solutions incorporated in dental stone on setting expansion, compression and flexural strength of dental models
}

\author{
LUMINIȚA OANCEA ${ }^{1}$, LORELAI GEORGETA BILINSCHI ${ }^{2}$, MIHAI BURLIBAȘA ${ }^{*}$, \\ ALEXANDRU PETRE ${ }^{1}$, MARIN SANDU ${ }^{3}$, ȘERBAN COSTELA ${ }^{4}$, BIANCA DELIU ${ }^{1}$, \\ GABRIELA TĂNASE ${ }^{1}$, VIOREL ȘTEFAN PERIEANU ${ }^{1}$, RADU COSTEA ${ }^{1}$, MĂDĂLINA \\ VIOLETA PERIEANU ${ }^{1}$, MIHAI DAVID ${ }^{1}$, OANA CELLA ANDREI ${ }^{1}$, MĂDĂLINA ADRIANA \\ MALITTA $^{1}$, NARCIS MARCOV ${ }^{1}$, MIHAELA ROMANIT,A GLIGOR ${ }^{5}$, CAMELIA IONESCU ${ }^{1}$, \\ BOGDAN PAVĂL ${ }^{5}$, CORINA MARILENA CRISTACHE ${ }^{1}$, ILEANA IONESCU ${ }^{1}$

\footnotetext{
1"Carol Davila" University of Medicine and Pharmacy Bucharest, Romania

${ }^{2}$ University of Medicine and Pharmacy Targu Mures, Romania

${ }^{3}$ University Politehnica of Bucharest, Romania

"'Victor Babes" University of Medicine and Pharmacy Timisoara, Romania

5"Lucian Blaga" University of Sibiu, Romania

${ }^{6}$ Private Dental Office, Romania
}

\begin{abstract}
Purpose of the study: The aim of the study is to analyze the way the disinfectants embedded in the plaster affect the setting linear dimensional stability, flexural and compressive strength of dental stone models.

Material and Methods: Samples were made of type IV dental stone in which different disinfectants had been incorporated (sodium hypochlorite 1\%, chlorhexidine $2 \%$ ) in two concentrations $(50 \%, 100 \%)$, thus obtaining four test groups. Mentioned parameters are measured using a micro comparison device and an universal testing machine, analyzing statistically the results in comparison with the control group, prepared by standard indications.

Results: Disinfectants cause a decrease of the setting expansion value $(\Delta \mathrm{L})$ compared to the standard group in all type of mixing percentage. Variations of compressive and flexural strength are statistically significant, particularly when adding $100 \%$ of hypochlorite $1 \%$.

Conclusions: Within the limits of this study, replacing the distilled water with disinfectants, alter the value of setting expansion and cause the model dental stone to be brittle in compression and bending.
\end{abstract}

Keywords Dental stone models, disinfection.

To cite this article: OANCEA L, BILINSCHI LG, BURLIBAȘA M, PETRE A, SANDU M, COSTELA S, DELIU B, TĂNASE G, PERIEANU VȘ, COSTEA R, PERIEANU MV, DAVID M, ANDREI OC, MALIȚA MA, NARCIS MARCOV, GLIGOR MR, IONESCU C, PAVĂL B, CRISTACHE CM, IONESCU I. Effects of disinfectant solutions incorporated in dental stone on setting expansion, compression and flexural strength of dental models. Rom Biotechnol Lett. 2020; 25(6): 2095-2102. DOI: 10.25083/rbl/25.6/2095.2102 


\section{Introduction}

In dentistry, dental impressions and models are considered potentially contaminated sources with various pathogens from patients' blood and saliva. The most commonly disinfection methods used in the dental office and dental laboratory are immersion (ABDULLAH, KUMAR \& al, PAL \& al [1-3]) or spraying with disinfectants (MANSFIELD \& al, STERN \& al [4-5]) of the models, but each method has its advantages and disadvantages.

In the attempt to find an optimum method to reduce, the risk of cross-contamination, Donovan Chee [6] tested a new dental stone for models (Steride) in 1989, which contained Chloramine-T. After conducting tests, the authors reported physical properties comparable with those of classic dental stone in almost all aspects.

Schutt [7] also reported that by using Steride product the same disinfection had been obtained for the dental impression of an irreversible hydrocolloid as for the die cast, after 60 minutes from the setting of the dental stone.

Tebrock et al. [8] concluded in their study that the die cast without microbial contamination could be obtained by replacing the distilled water necessary for preparing of the dental stone in a ratio of $25 \%$, with $5.25 \%$ sodium hypochlorite.

Other studies (ZARAKANI \& al, SWATANTRA \& al $[9,10])$ which tests the same hypothesis, conclude that replacing the distilled water with sodium hypochlorite has no effect on the setting time, the setting expansion or compressive strength of the model obtained, recommending this method of disinfection in dental labs.

However, contradicting earlier studies, Breault L.G. [11] has examined the quality of the die dental stone, replacing $10 \%$ of the water with $5.25 \%$ sodium hypochlorite solution, and concluded that this modification increases the compressive strength and the rigidity of the dental stone, without changes in terms of tensile strength or setting expansion.

K.M. Abdelaziz [12] tested the resistance on compression and tensile forces of modified dental stone and showed that disinfectants reduced the hardness of both types of die stone, contradicting the findings of Breault.
However, studying the influence of incorporation of disinfectants in dental stone, Lucas M.G. [13] pointed out that the addition of sodium hypochlorite in both dilutions significantly alters all of the properties examined. On the contrary, the addition of glutaraldehyde or chlorhexidine in the structure of the dental stone had no significant changes.

The results communicated so far in the literature are quite controversial. The purpose of the present study is to analyze how two commonly disinfectants / antiseptics incorporated in different percentages in dental stone, affect the linear dimensional stability, flexural and compressive strength of the dental models.

\section{Materials and Methods}

The present study was conducted in an environment with temperature of $25^{\circ} \mathrm{C}\left( \pm 2{ }^{\circ} \mathrm{C}\right)$ and relative humidity of $50 \%( \pm 10 \%)$, according to the American Dental Association Specification (A.D.A.) No. 25.

The materials used were type IV super hard cast dental stone INFRAROCK (INFRADENT), sodium hypochlorite $1 \%$, chlorhexidine gluconate $2 \%$. The instruments used were caliper, an expansion-measuring device (SAM EMI 100), and an universal testing machine.

The study was conducted on 5 groups as follows:

- GROUP 1: control (dental stone is prepared according to manufacturer's instructions);

- GROUP 2: replacement of $100 \%$ of the water with sodium hypochlorite $1 \%$;

- GROUP 3: replacement of $50 \%$ of the water with sodium hypochlorite $1 \%$;

- GROUP 4: replacement of $100 \%$ of the water with chlorhexidine gluconate $2 \%$;

- GROUP 5: replacement of $50 \%$ of the water with chlorhexidine gluconate $2 \%$;

The dental stone was prepared with vacuum mixer and then placed in the container of expansion-measuring device under vibration; this device will measure the expansion setting and dimensional change $(\Delta \mathrm{L})$ up to two hours.

The sample, after setting, was removed from the container and measured using a caliper, to determine the length (L); the length on initial setting was then calculated: $\mathrm{L}_{\mathrm{o}}=\mathrm{L}-\Delta \mathrm{L}$. The percentage of dimensional change was calculated: $\mathrm{ADL}=\Delta \mathrm{L} / \mathrm{L}_{\mathrm{o}} \times 100$.
A.

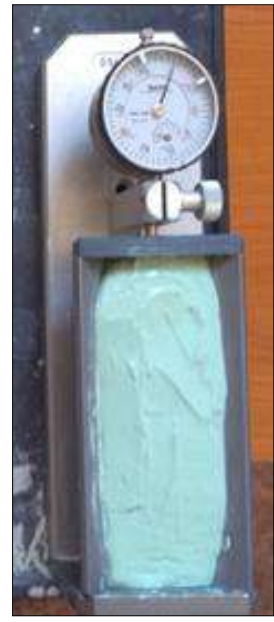

B.

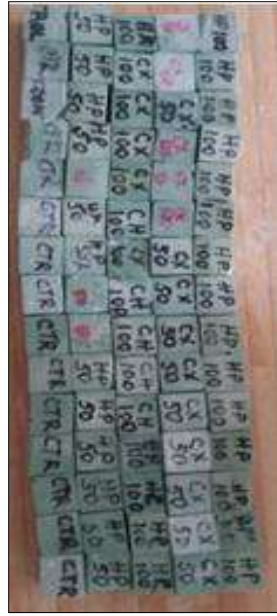

C.

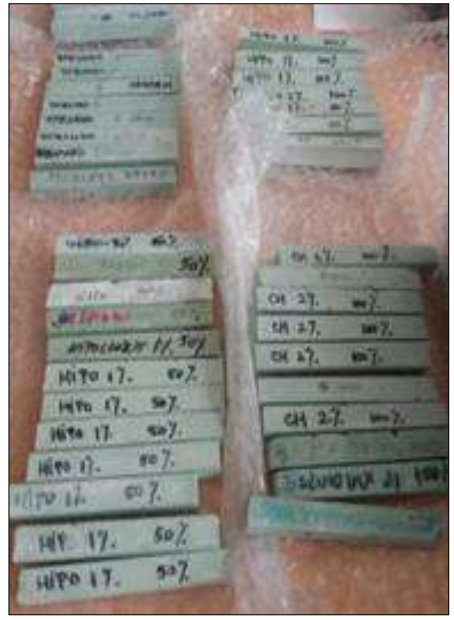

Figure 1. Samples prepared for testing:

A. Setting linear changes; B. Resistance to bending forces; C. Resistance to compression forces. 
After the dimensional measurements, the samples were prepared for the strength tests by converting into a rectangular form $10 \mathrm{~cm}$ long and $4 \mathrm{~mm}^{2}$ per section. 5 samples presenting casting defects were removed. Among samples considered valid, a number of 15 or cut to standard sizes, each sample into five equal parts, resulting cubes with $2 \mathrm{~cm}$ side - samples for compression tests. Samples were then loaded on the universal-testing machine and the results were recorded as graphics by computer.
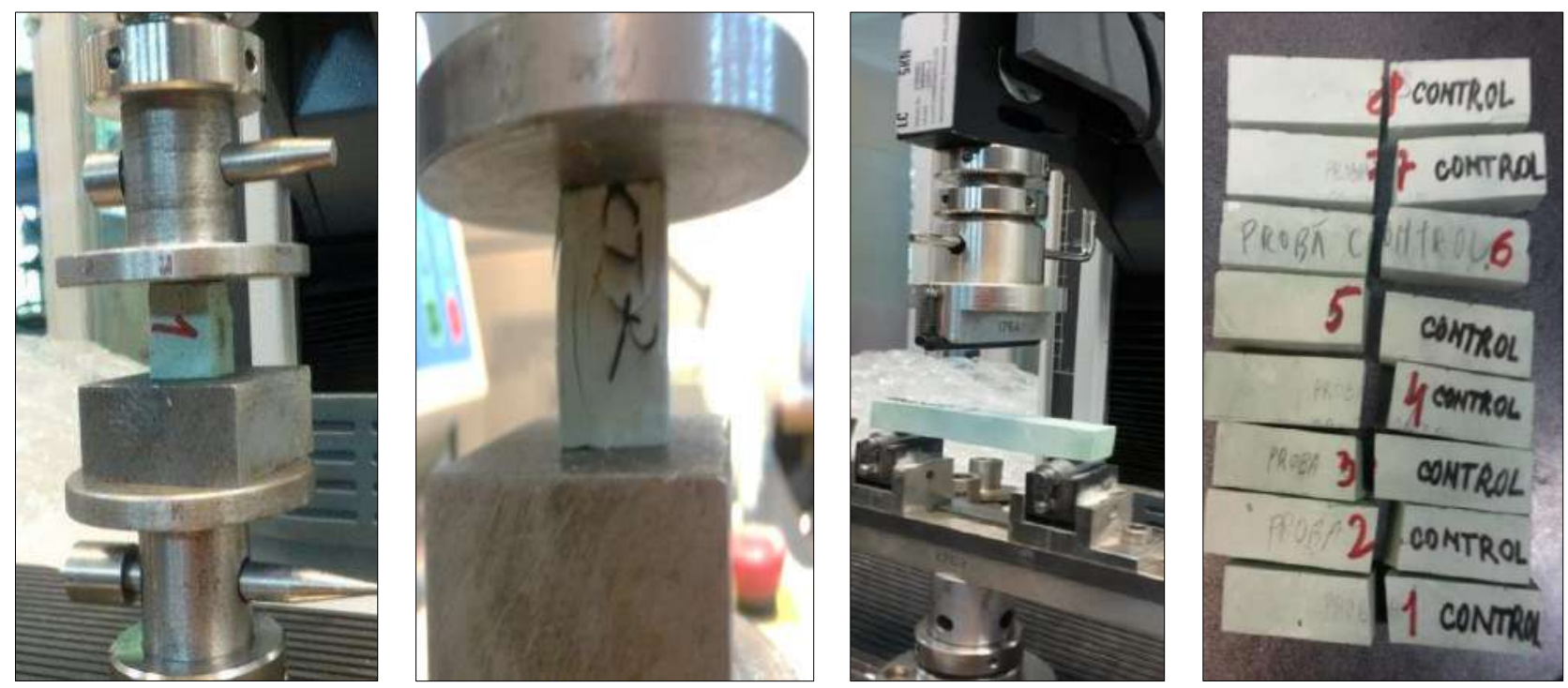

Figure 2. Samples loaded for compression and bending test.

\section{Results}

\section{The results of dimensional changes}

Results recorded after the measurement of parameters $\mathrm{L}_{0}, \mathrm{~L}$ and ADL were summarized in a table and statistically analyzed.

For the parameter $\mathrm{L}_{0}$ the ANOVA test has been applied $(\mathrm{F}(4.49)=3.9, \mathrm{p}=0.008)$ with planned contrasts to see if the averages of four groups (2, 3, 4 and 5) were different than the standard group (1). The average Group 2 was significantly higher than the standard group, $\mathrm{t}(45)=$ $2.85, \mathrm{p}=0.007$. For the group $3(\mathrm{p}=0.508)$, the group 4 $(\mathrm{p}=0.404)$ and group $5(\mathrm{p}=0.975)$ averages were not significantly different from the standard group.

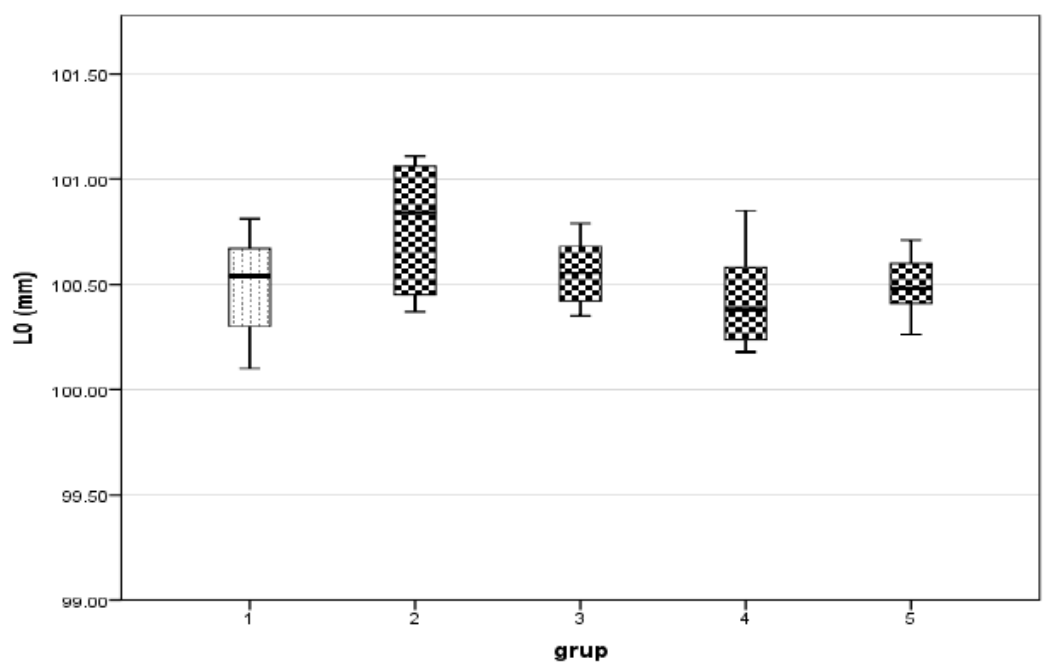

Graphic 1. Comparative analysis of samples size at the initial setting, $\mathrm{L}_{0}$.

For the parameter L, the ANOVA test has been applied $(\mathrm{F}(4.49)=3.5, \mathrm{p}=0.014)$ with planned contrasts to see if the averages of four groups (2, 3, 4 and 5) were different from the standard group (1).
The average Group 2 was significantly higher than the standard group, $\mathrm{t}(45)=2.51, \mathrm{p}=0.016$. For Group 3 $(\mathrm{p}=0.787)$, Group $4(\mathrm{p}=0.312)$ and group $5(\mathrm{p}=0.803)$, the averages were not significantly different from the standard group. 


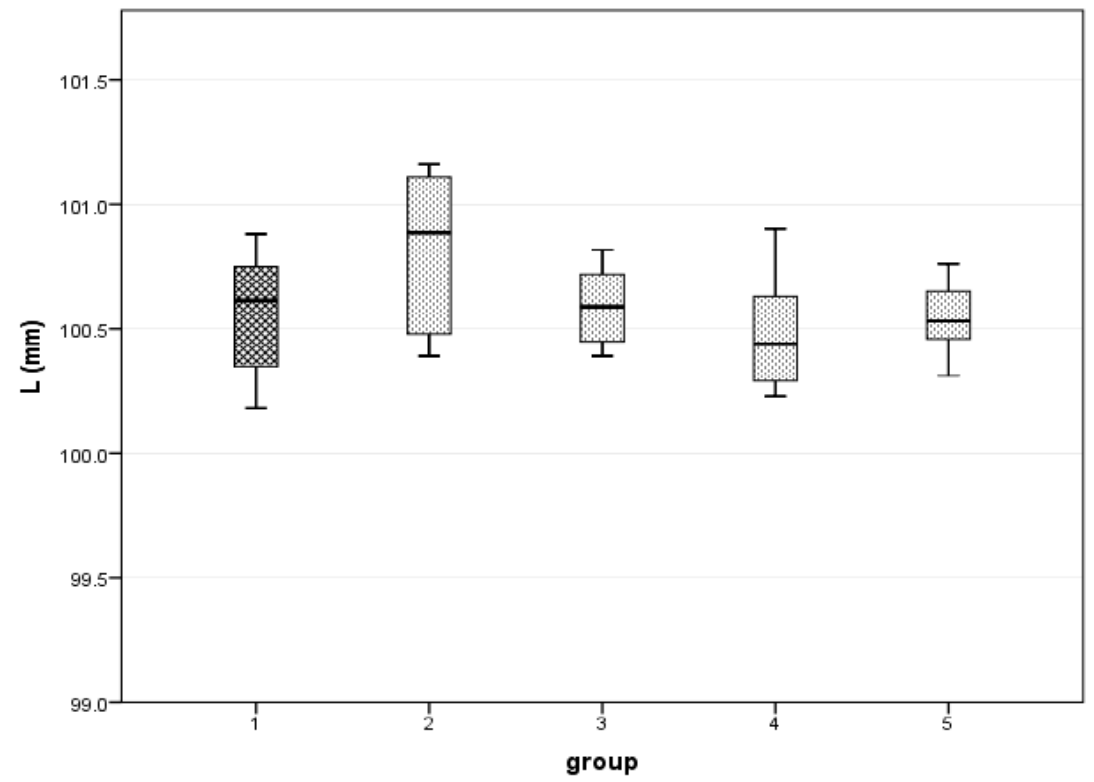

Graphic 2. Comparative analysis of samples size at final setting L.

For the parameter $\Delta \mathrm{L}$, the ANOVA test has been applied $(\mathrm{F}(4.49)=34.1, \mathrm{p}<0.001)$ with planned contrasts to see if the averages of four groups (2, 3, 4 and 5) are different than the standard group (1). We found that all groups average were significantly lower than the standard group, as follows: Group $2 \mathrm{t}(17.9)=-6.76, \mathrm{p}<0.001$; group $3 \mathrm{t}(13.5)=-10.44, \mathrm{p}<0.001$; Group 4, $\mathrm{t}(14.3)=-5.52$, $\mathrm{p}<0.001$; group $5, \mathrm{t}(8.12)=-6.03, \mathrm{p}<0.001$.

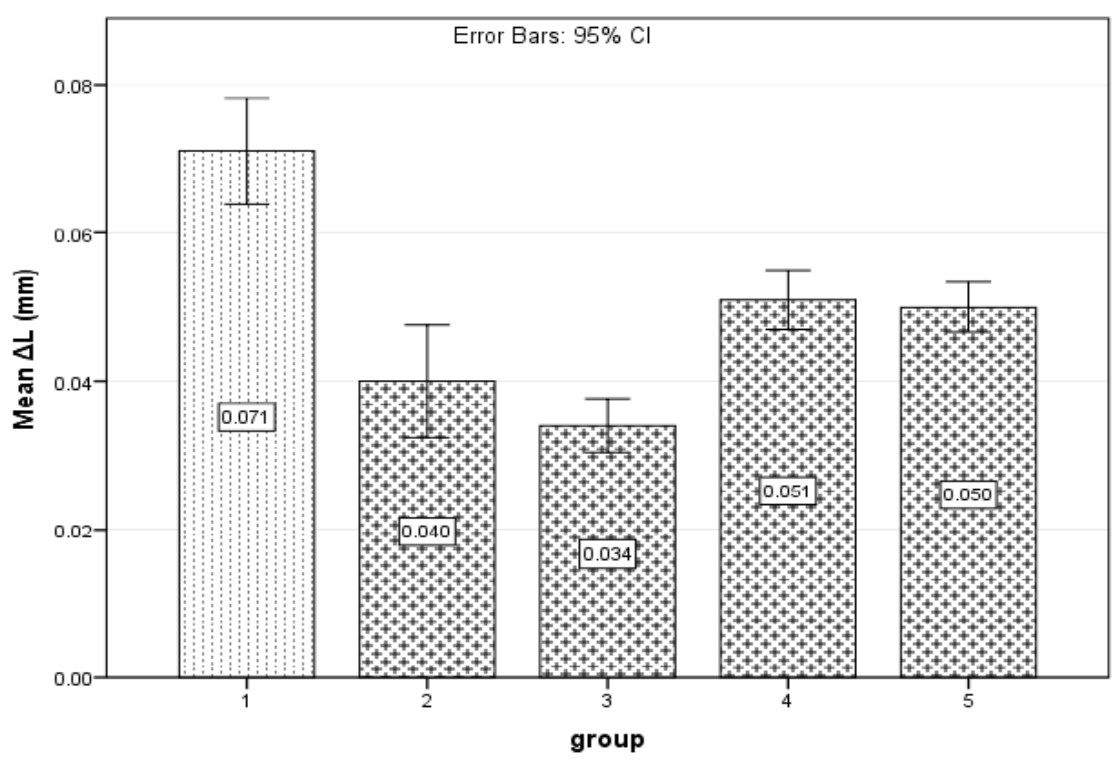

Graphic 3. Comparative analysis of dimensional change of samples $\Delta \mathrm{L}$.

For the ADL parameter, we have applied ANOVA test $(\mathrm{F}(4.49)=34.1, \mathrm{p}<0.001)$ with planned contrasts to see if the averages of four groups (2,3, 4 and 5) were different than the standard group (1). We found that all the groups had the average significantly lower than the standard group, as follows: Group 2, $\mathrm{t}(17.9)=-6.76$, $\mathrm{p}<0.001$; Group 3, $\mathrm{t}(13.5)=-10.44, \mathrm{p}<0.001$; Group 4, $\mathrm{t}(14.3)=-5.52, \mathrm{p}<0.001 ;$ group $5, \mathrm{t}(12.8)=-6.03$, $\mathrm{p}<0.001$. 
When recording original setting length $\left(\mathrm{L}_{0}\right)$, statistical analysis revealed a significantly higher difference compared to the test control group in groups where all the water had been replaced by sodium hypochlorite/disinfectant, which intensified setting expansion. The remaining combinations showed no changes. Dimensional change after addition of sodium hypochlorite was expected, but because this substance is known to be an inhibitor of the setting reaction, the result is different from that obtained in our previous study (A.D.A., SFARGHIU \& al [14, 15]), reports being done this time to the average of the control group tests.

After two hours of the initial setting (L), changes of chlorhexidine and $50 \%$ sodium hypochlorite $1 \%$ groups are insignificant compared to the control group.

Statistically analyzing the average of setting expansion values $(\Delta \mathrm{L})$ versus standard group, a decrease in all variants in which antiseptic were used has been observed, as well as in calculating percentage dimensional changes in control group. The results are similar to data from Renz and Martin' studies (RENTZIA \& al, MARTIN \& al [16, 17]), pointing out that chemical agents which adjust the setting time generally reduce the mass expansion of dental stone obtained from the hydration of calcium sulphate.

\section{Compression test results}

Using a universal loading machine Zwick Roell with $10 \mathrm{kN}$ nominal load, rectangular samples were tested to compression. Samples have a section of the $a^{*} a$ and height $h$. The values were $\mathrm{a}=15 \mathrm{~mm}$ and $\mathrm{h}=20 \mathrm{~mm}$. Opposite sides, were load was applied were perfectly flat and parallel only to some of the specimens. Thus, in most cases, failure (breaking) was produced progressively, starting from the most prominent areas. Therefore, shortened force curves have been obtained (Fig. 3) in a zigzag shape and breaking forces had lower values than specimens without deficiencies. In Figure 4 all curves recorded are shown on the same graph.

For each series of tests, were detained ten results for samples where failure forces had had highest values. Breaking tensions and the compressive modulus of elasticity were determined by the following equations:

$$
\sigma_{\text {rup }}=\frac{F_{\text {rup }}}{a^{2}} \quad E=\frac{\Delta F}{a^{2}} \cdot \frac{h}{\Delta h}
$$

Variations of and are considered on a linear area of shortening-force curve.

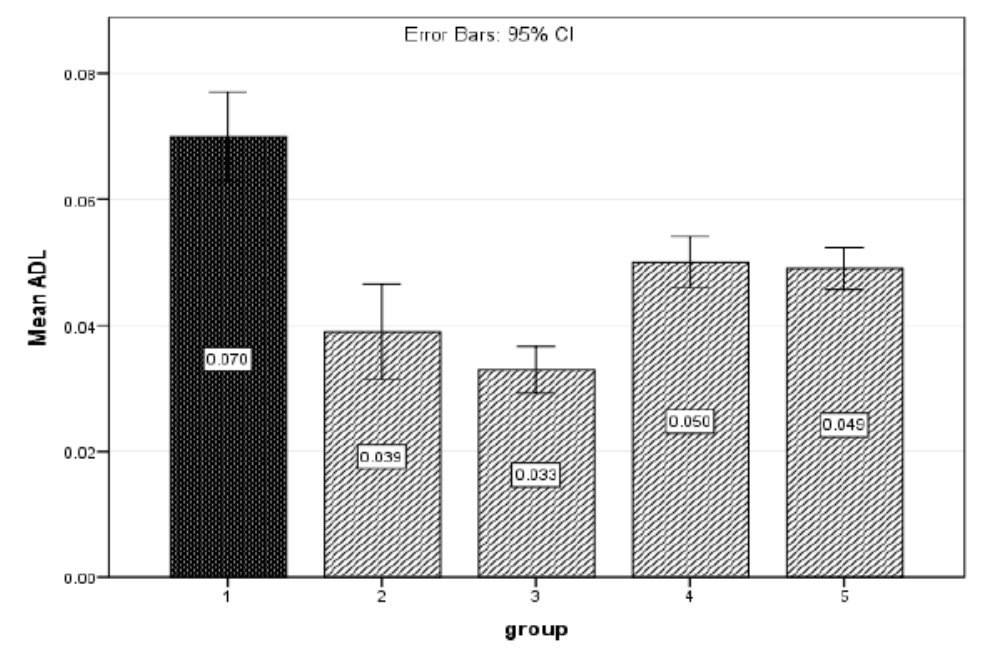

Graphic 4. Variation of the dimensional change of ADL.

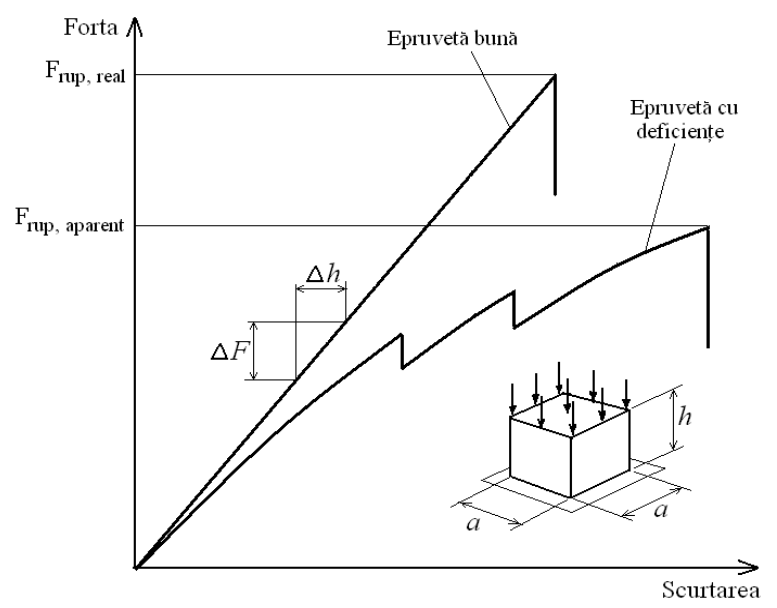

Figure 3. Force curve shortened in zigzag shape.

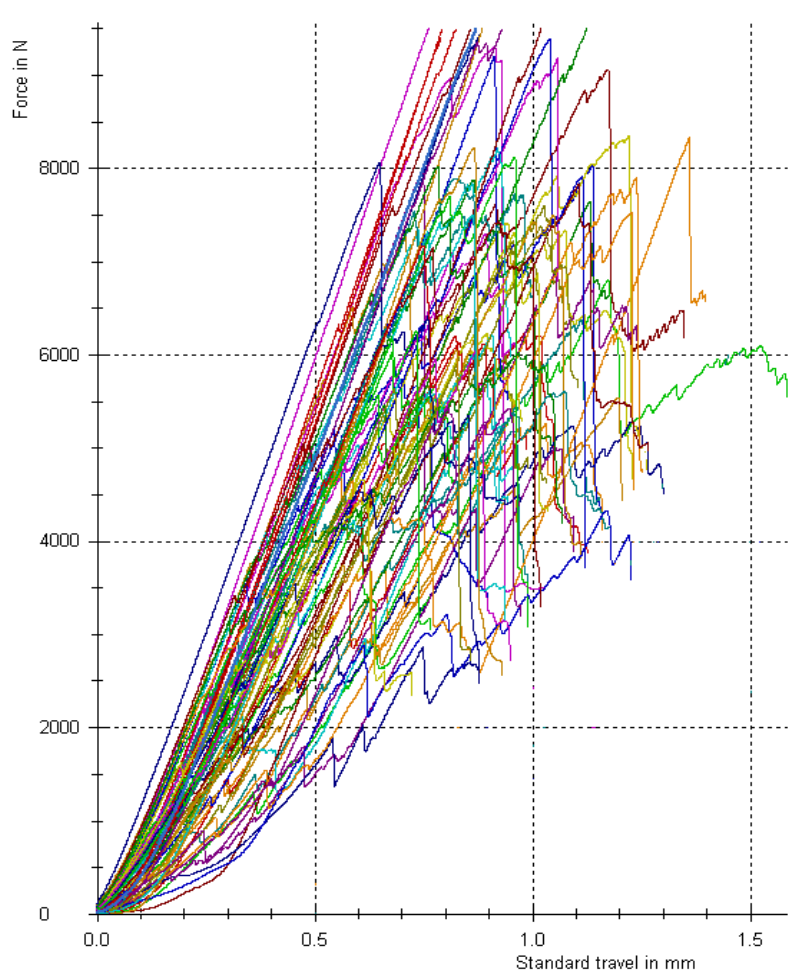

Figure 4. Curves recorded in the test compression. 
Tabel VII. CTR (grup control)

\begin{tabular}{|l|l|l|}
\hline Proba & $F_{\text {rup }}[\mathrm{N}]$ & $\sigma_{\text {rup }}[\mathrm{MPa}]$ \\
\hline CTR 1 & 9200 & 40,9 \\
\hline CTR 2 & 7900 & 35,1 \\
\hline CTR 3 & 9190 & 40,8 \\
\hline CTR 4 & 8220 & 36,5 \\
\hline CTR 5 & 9860 & 43,8 \\
\hline CTR 6 & 9500 & 42,2 \\
\hline CTR 7 & 9680 & 43,0 \\
\hline CTR 8 & 7740 & 34,4 \\
\hline CTR 9 & 7230 & 32,1 \\
\hline CTR 10 & 9920 & 44,1 \\
\hline
\end{tabular}

Tabel IX. HI 100 (grup 2)

\begin{tabular}{|l|l|l|}
\hline Proba & $F_{\text {rup }}[\mathrm{N}]$ & $\sigma_{\text {rup }}[\mathrm{MPa}]$ \\
\hline HI 1001 & 6370 & 28,3 \\
\hline HI 1002 & 7500 & 33,3 \\
\hline HI 1003 & 7430 & 33,0 \\
\hline HI 1004 & 6220 & 27,6 \\
\hline HI 1005 & 8220 & 36,5 \\
\hline HI 1006 & 6190 & 27,5 \\
\hline HI 1007 & 6040 & 26,8 \\
\hline HI 1008 & 7180 & 31,9 \\
\hline HI 1009 & 6260 & 27,8 \\
\hline HI 10010 & 9510 & 42,2 \\
\hline$\sigma_{\text {rup }, \text { med }}=31,5 \mathrm{Mpa} E_{\text {med }}=1040 \mathrm{MPa}$
\end{tabular}

Tabel VIII. HI 50 (grup 3)

\begin{tabular}{|l|l|l|}
\hline Proba & $F_{\text {rup }}[\mathrm{N}]$ & $\sigma_{\text {rup }}[\mathrm{MPa}]$ \\
\hline HI 50 1 & 9400 & 41,7 \\
\hline HI 502 & 7530 & 33,4 \\
\hline HI 503 & 9860 & 43,8 \\
\hline HI 504 & 7830 & 34,8 \\
\hline HI 50 5 & 8020 & 35,6 \\
\hline HI 506 & 8070 & 35,8 \\
\hline HI 50 7 & 9790 & 43,5 \\
\hline HI 508 & 7900 & 35,1 \\
\hline HI 509 & 9910 & 44,0 \\
\hline HI 5010 & 8120 & 36,1 \\
\hline
\end{tabular}

Tabel X. CX 50 (grup 5)

\begin{tabular}{|l|l|l|}
\hline Proba & $F_{\text {rup }}[\mathrm{N}]$ & $\sigma_{\text {rup }}[\mathrm{MPa}]$ \\
\hline CX 50 1 & 6230 & 27,6 \\
\hline CX 50 2 & 6810 & 30,2 \\
\hline CX 50 3 & 5760 & 25,6 \\
\hline CX 50 4 & 9310 & 41,3 \\
\hline CX 50 5 & 5750 & 25,5 \\
\hline CX 50 6 & 7410 & 32,9 \\
\hline CX 50 7 & 9620 & 42,7 \\
\hline CX 50 8 & 7870 & 34,9 \\
\hline CX 50 9 & 5740 & 25,5 \\
\hline CX 50 10 & 7980 & 35,4 \\
\hline
\end{tabular}

Tabel XI. CX 100 (grup 4)

\begin{tabular}{|l|l|l|}
\hline Proba & $\mathrm{F}_{\text {rup }}[\mathrm{N}]$ & $\sigma_{\text {rup }}[\mathrm{MPa}]$ \\
\hline CX 1001 & 8040 & 35,7 \\
\hline CX 1002 & 8330 & 37,0 \\
\hline CX 1003 & 7300 & 32,4 \\
\hline CX 1004 & 8350 & 37,1 \\
\hline CX 1005 & 9060 & 40,2 \\
\hline CX 1006 & 7650 & 34,0 \\
\hline CX 100 7 & 9430 & 41,9 \\
\hline CX 100 8 & 7260 & 32,2 \\
\hline CX 1009 & 7600 & 33,7 \\
\hline CX 100 10 & 9400 & 41,7 \\
\hline
\end{tabular}

Figure 5. The results recorded on study groups in compression test.

In conclusion, $\sigma_{\text {rup,med }}=2<5<4<3<1, E_{\text {med }}=$ $2<1<5<3<4$.

Compressive breaking tension values in all cases were lower than in the control group, the brittle samples are those with the addition of $100 \%$ sodium hypochlorite $1 \%$, followed by the group with $50 \%$ chlorhexidine gluconate $2 \%, 100 \%$ gluconate $2 \%$ chlorhexidine, $50 \%$ water with $1 \%$ sodium hypochlorite; compression modulus of elasticity decreased when $100 \%$ addition of hypochlorite, while in other cases, increased compared to the control group. The study results contradict previous studies mentioned (ZARAKANI \& al, SWATANTRA $\&$ al, BREAULT \& al. [9, 10, 11]), showing that the addition of disinfectants have influence on quality of dental stone for models.

\section{Flexural test results}

Flexural strength of samples was tested in an universal loading machine from Lloyd Instruments LRX plus with nominal load of $5 \mathrm{kN}$. Samples were processed to rectangular section of $\mathrm{a}^{*} \mathrm{a}$ and a length of $100 \mathrm{~mm}$. Requirements were $\mathrm{a}=15 \mathrm{~mm}$, but processing was grossly and deviations were detected quite high of the odds. Therefore, actual values for each sample have been considered.

In Figure no 6 the charging scheme commonly called "three-point bending" is shown.

The distance between the support rollers was $1=80 \mathrm{~mm}$. 


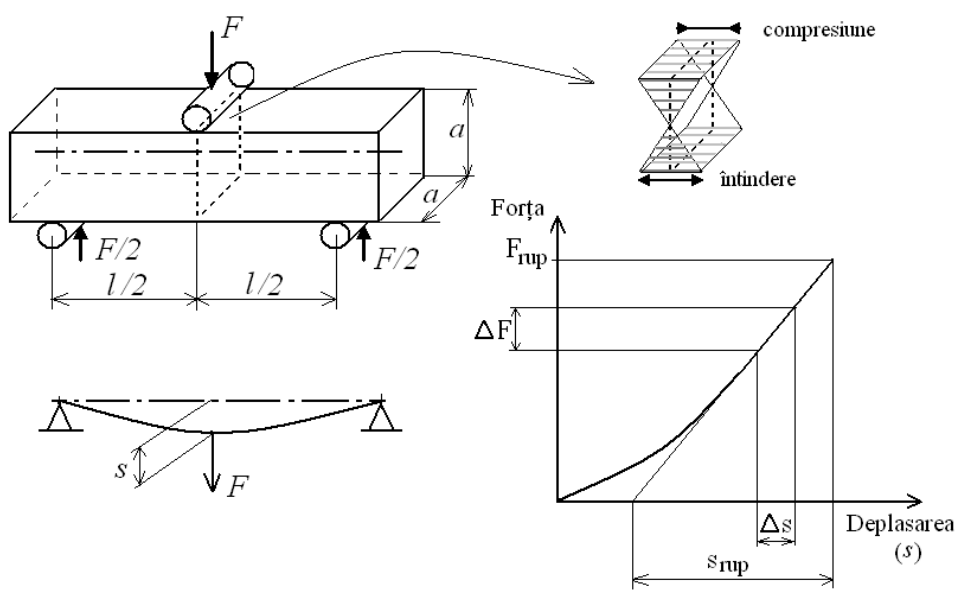

Figure 6. Loading scheme

Breaking tension and compression modulus of elasticity were determined with the known relationship from the resistance of materials:

$$
\sigma_{\text {rup }}=\frac{F_{\text {rup }} \cdot l}{4 \cdot W}, \quad E=\frac{\Delta F \cdot l^{3}}{48 \cdot I \cdot \Delta s},
$$

In which $I=\frac{a^{4}}{12}, W=\frac{a^{3}}{6}$, and variations $\Delta F$ and of $\Delta h$ are considered on a linear area of displacementforce curve.

The middle section of the sample is the most strained, therefore deformations occur and longitudinal tensions have extremes values, with stretching on the lower surface and compression on the top surface.

Tabel XII. CTR (grup control)
\begin{tabular}{|l|lll|l|l|l|l|l}
\hline Proba & Sectiune & $\begin{array}{l}\text { I } \\
{\left[\mathrm{mm}^{4}\right]}\end{array}$ & $\begin{array}{l}W \\
{\left[\mathrm{~mm}^{3}\right]}\end{array}$ & $\begin{array}{l}F_{\text {rup }} \\
{[\mathrm{N}]}\end{array}$ & $\begin{array}{l}\Delta F \\
{[\mathrm{~N}]}\end{array}$ & $\begin{array}{l}\Delta s \\
{[\mathrm{~mm}]}\end{array}$ & $\begin{array}{l}\sigma_{\text {rup }} \\
{[\mathrm{MPa}]}\end{array}$ & $\begin{array}{l}E \\
{[\mathrm{MPa}]}\end{array}$ \\
\hline CTR 1 & $15,5 \times 15,5$ & 4810 & 620,6 & 470 & 225 & 0,2 & 15,1 & 2494 \\
\hline CTR 2 & $15,5 \times 15,5$ & 4810 & 620,6 & 471 & 271 & 0,22 & 15,1 & 2731 \\
\hline CTR 3 & $15 \times 15$ & 4218 & 562,5 & 400 & 165 & 0,15 & 14,2 & 2781 \\
\hline CTR 4 & $15 \times 15$ & 4218 & 562,5 & 390 & 190 & 0,16 & 13,9 & 3003 \\
\hline CTR 5 & $16 \times 16$ & 5461 & 682,6 & 531 & 231 & 0,16 & 15,5 & 2820 \\
\hline CTR 6 & $15,5 \times 15,5$ & 4810 & 620,6 & 436 & 236 & 0,2 & 14,0 & 2616 \\
\hline CTR 7 & $15 \times 15$ & 4218 \\
$\sigma$
\end{tabular}

Tabel XIII. HI 1\% 50\% (grup 3)

\begin{tabular}{|c|c|c|c|c|c|c|c|c|}
\hline Proba & Sectiune & $\begin{array}{l}I \\
{\left[\mathrm{~mm}^{4}\right]}\end{array}$ & $\begin{array}{l}W \\
{\left[\mathrm{~mm}^{3}\right]}\end{array}$ & $\begin{array}{l}F_{\text {rup }} \\
{[\mathrm{N}]}\end{array}$ & $\begin{array}{l}\Delta F \\
{[N]}\end{array}$ & $\begin{array}{l}\Delta s \\
{[\mathrm{~mm}]}\end{array}$ & $\begin{array}{l}\sigma_{r u p} \\
{[\mathrm{MPa}]}\end{array}$ & $\begin{array}{l}E \\
{[\mathrm{MPa}]}\end{array}$ \\
\hline HI 501 & $15 \times 15$ & 4218 & 562,5 & 379 & 178 & 0,146 & 13,4 & 3082 \\
\hline HI 502 & $16 \times 16$ & 5461 & 682,6 & 445 & 202 & 0,147 & 13,0 & 2684 \\
\hline HI 503 & $16 \times 16$ & 5461 & 682,6 & 463 & 233 & 0,187 & 13,5 & 2433 \\
\hline HI 504 & $15,5 \times 15,5$ & 4810 & 620,6 & 439 & 239 & 0,188 & 14,1 & 2819 \\
\hline HI 505 & $15,5 \times 15,5$ & 4810 & 620,6 & 452 & 252 & 0,218 & 14,5 & 2563 \\
\hline HI 506 & $15 \times 15$ & 4218 & 562,5 & 366 & 165 & 0,129 & 13,0 & 3234 \\
\hline HI 507 & $15 \times 15$ & 4218 & 562,5 & 343 & 143 & 0,134 & 12,2 & 2698 \\
\hline HI 508 & $16,5 \times 16,5$ & 6176 & 748,7 & 538 & 238 & 0,186 & 14,3 & 2210 \\
\hline HI 509 & $16 \times 16$ & 5461 & 682,6 & 443 & 143 & 0,122 & 13,0 & 2289 \\
\hline HI 5010 & $16,5 \times 16,5$ & 6176 & 748,7 & 471 & 190 & 0,161 & 12,6 & 2038 \\
\hline
\end{tabular}

Tabel XIV. HI 1\% 100\% (grup 2)

\begin{tabular}{|c|c|c|c|c|c|c|c|c|}
\hline Proba & Sectiune & $\begin{array}{l}I \\
{\left[\mathrm{~mm}^{4}\right]}\end{array}$ & $\begin{array}{l}W \\
{\left[\mathrm{~mm}^{3}\right]}\end{array}$ & $\begin{array}{l}F_{\text {rup }} \\
{[\mathrm{N}]}\end{array}$ & $\begin{array}{l}\Delta F \\
{[N]}\end{array}$ & $\begin{array}{l}\Delta s \\
{[\mathrm{~mm}]}\end{array}$ & $\begin{array}{l}\sigma_{\text {rup }} \\
{[\mathrm{MPa}}\end{array}$ & $\begin{array}{l}E \\
{[\mathrm{MPa}]}\end{array}$ \\
\hline HI 1001 & $15 \times 15$ & 4218 & 562,5 & 363 & 44 & 0,042 & 12,9 & 2649 \\
\hline HI 1002 & $16 \times 16$ & 5461 & 682,6 & 479 & 249 & 0,207 & 14,0 & 2349 \\
\hline HI 1003 & $16 \times 16$ & 5461 & 682,6 & 475 & 279 & 0,242 & 13,9 & 2251 \\
\hline HI 1004 & $15,5 \times 15,5$ & 4810 & 620,6 & 433 & 233 & 0,178 & 13,9 & 2902 \\
\hline HI 1005 & $15 \times 15$ & 4218 & 562,5 & 327 & 126 & 0,109 & 11,6 & 2923 \\
\hline HI 1006 & $15 \times 15$ & 4218 & 562,5 & 335 & 134 & 0,125 & 11,9 & 2710 \\
\hline HI 1007 & $15,5 \times 15,5$ & 4810 & 620,6 & 457 & 219 & 0,185 & 14,7 & 2625 \\
\hline
\end{tabular}

\begin{tabular}{|c|c|c|c|c|c|c|c|c|}
\hline Proba & Sectiune & $\begin{array}{l}I \\
{\left[\mathrm{~mm}^{4}\right]}\end{array}$ & $\begin{array}{l}W \\
{\left[\mathrm{~mm}^{3}\right]}\end{array}$ & $\begin{array}{l}\text { Frup } \\
{[\mathrm{N}]}\end{array}$ & $\begin{array}{l}\Delta F \\
{[N]}\end{array}$ & $\begin{array}{l}\Delta s \\
{[\mathrm{~mm}]}\end{array}$ & $\begin{array}{l}\sigma_{\text {rup }} \\
{[\mathrm{MPa}]}\end{array}$ & $\begin{array}{l}E \\
{[\mathrm{MPa}]}\end{array}$ \\
\hline $\mathrm{CX} 501$ & $15,5 \times 15,5$ & 4810 & 620,6 & 375 & 201 & 0,17 & 12,1 & 2622 \\
\hline $\mathrm{CX} 502$ & $15 \times 15$ & 4218 & 562,5 & 365 & 171 & 0,14 & 13,0 & 3088 \\
\hline $\mathrm{CX} 503$ & $15,5 \times 15,5$ & 4810 & 620,6 & 386 & 186 & 0,152 & 12,4 & 2713 \\
\hline $\mathrm{CX} 504$ & $15,5 \times 15,5$ & 4810 & 620,6 & 396 & 196 & 0,189 & 12,7 & 2300 \\
\hline $\mathrm{CX} 505$ & $16 \times 16$ & 5461 & 682,6 & 404 & 204 & 0,156 & 11,8 & 2554 \\
\hline CX 506 & $16 \times 16$ & 5461 & 682,6 & 408 & 208 & 0,172 & 11,9 & 2362 \\
\hline $\mathrm{CX} 507$ & $15,5 \times 15,5$ & 4810 & 620,6 & 384 & 183 & 0,137 & 12,4 & 2962 \\
\hline
\end{tabular}

Figure 7. Test results of bending strength on the studied groups. 
In conclusion, $\sigma_{\text {rup }, \text { med }}=5<2<3=4<1 ; \quad E_{\text {med }}=$ $3<2<5<1<4$.

Breaking bending (flexural) tension decreases in all situations where antiseptic was added. The breaking modulus of elasticity compared to the control increased by the addition of $100 \%$ chlorhexidine gluconate $2 \%$, while in all other circumstances there has been a decrease.

\section{Conclusions}

Within the limits of the method used in the current study, we can say that the addition of disinfectants in the dental stone caused the following changes:

$>$ When recording initial setting length $\left(\mathrm{L}_{0}\right)$, as well as after two hours after initial setting (L), statistical analysis revealed a significantly higher difference compared to the control group of tests, where all of the water had been replaced by sodium hypochlorite substance that has intensified setting expansion. The remaining combinations showed no changes;

$>$ Statistically analyzing the average of setting expansion values $(\Delta \mathrm{L})$ versus standard group, there is a decrease in all situations in which disinfectants were used, similar situation highlighted when calculating percentage dimensional change;

> Compressive breaking tension in all cases was lower than in the control group, the brittle samples are those with the addition of $100 \%$ sodium hypochlorite $1 \%$, followed by the group with $50 \%$ chlorhexidine gluconate $2 \%, 100 \%$ gluconate $2 \%$ chlorhexidine, $50 \%$ water with $1 \%$ sodium hypochlorite; compression modulus of elasticity decreased when $100 \%$ addition of hypochlorite, while in the other cases, increased compared to the control group.

$>$ Breaking flexural tension decreased in all situations where antiseptic has been added. The breaking modulus of elasticity compared to the control increased by the addition of $100 \%$ chlorhexidine gluconate $2 \%$, while in all other circumstances there has been a decrease.

\section{Acknowledgement}

In this article, all the authors have equal contributions to the first author.

\section{References}

1. M.A. ABDULLAH. Surface detail, compressive strength and dimensional accuracy of gypsum casts after repeated immersion in hypochlorite solution. J. Prosthet. Dent. June, 95(6), 462-468 (2006).

2. R.N. KUMAR, R.N. REDDY, S. KARTHIGEYAN, R. MANIKANDAN, The effect of repeated immersion of gypsum cast in sodium hypochlorite and glutaraldehyde on its physical properties. J Pharm Bioallied Science. August, (Suppl 2), S353-S357 (2012).

3. P.K. PAL, S. KAMBLE, R.R. CHAURASIA, et al. Evaluation of different disinfectants on dimensional accuracy and surface quality of type IV gypsum casts retrieved from elastomeric impression materials. J Int Oral Health. March, 6(3), 77-81 (2014).

4. S.M. MANSFIELD, J.M. WHITE. Antimicrobial effects from incorporation of disinfectants into gypsum casts. Int J Prosthodont. 4,180-185 (1991).

5. M.A. STERN, G.H. JOHNSON, L.B. TOOLSON. An evaluation of dental stones after repeated exposure to spray disinfectants: Part I. Abrasion and compressive strength. J Prosthet Dent. 5, 713-718 (1991).

6. T. DONOVAN, W. CHEE. Preliminary investigation of a disinfected gypsum die stone. Int J Prost. 2, 245-248 (1989).

7. K.W. SCHUTT. Bactericidal effect of disinfectant dental stone on irreversible hydrocolloid impressions and stone casts. J Prosthet Dent. 62, 605-607 (1989).

8. O.C. TEBROK, R.L. ENGELMEIER, T.G. MAYFIELD, et al. Managing dental impressions and casts of patients with communicable diseases. Gen Dent. 37, 490-495 (1989).

9. H. ZARAKANI, N. KARIMI, S. SADRIYA, A. FAYAZ. Comparison of setting time, setting expansion and compressive strength of gypsum casts produced by mixing of gypsum powder with distilled water or $0.05 \%$ sodium hypochlorite. J Dent Sch. 31(2), 89-96 (2013).

10. A. SWATANTRA, G. KAVITA. An evaluation of properties of die stone after adding antimicrobial agents. J. of Pierre Fauchard Academy (India Section). December, 22(4), 131-139 (2008).

11. L.G. BREAULT, J.R. PAUL, S.O. HONDRUM, L.C. CHRISTENSEN. Die stone disinfection: Incorporation of sodium hypochlorite. J Prosthod. March, 7(1), 13-16 (1998).

12. K.M. ABDELAZIZ, E.C. COMBE, J.S. HODGES. The effect of disinfectants on the properties of dental gypsum: mechanical properties. J Prosthod. September, 11(3), 161-167 (2002).

13. M.G. LUCAS, J.N. ARIOLI-FILHO, S.S. NOGUEIRA, et al. Effect of incorporation of disinfectant solutions on setting time, linear dimensional stability and detail reproduction in dental stone casts. J Prosthod. August, 18(6), 521-526 (2009).

14. AMERICAN DENTAL ASSOCIATION: Specification No. 25 for dental gypsum products. In $A D A$ : Guide to dental materials and devices. Chicago, ADA, 1972/1973, pp. 253-258.

15. L.G. SFARGHIU, L. OANCEA, R. LIȚESCU, et al. The Influence of disinfectants incorporation on die stone linear expansion. Rom Biotechnol Lett. 21 (3), 11585-11590 (2016).

16. A. RENTZIA., D.C COLEMAN., M.J. O’DONNELL, et al. Disinfection procedures: Their efficacy and effect on dimensional accuracy and surface quality of an irreversible hydrocolloid impression. J of Dent. 39, I33 - I40 (2011).

17. N. MARTIN, M.V MARTIN., N.M. JEDYNAKIEWICZ. The dimensional stability of dental impression materials following immersion in disinfecting solutions. Dent Mat. 23, 760-768 (2007). 